\title{
Antihyperlipidemic Activity of Ethanol Extract Mindi's Leaves (Melia azedarach Linn.) in Male Wistar Rats Induced Propiltiouracil
}

\author{
Herlina $^{1 *}$, Budi Untari ${ }^{1}$, Indah Solihah ${ }^{1}$, Merie Santia ${ }^{1}$ \\ ${ }^{1}$ Departement of Pharmacy, Faculty of Mathematic and Natural Sciences, Sriwijaya University, Indonesia \\ *Corresponding author: rinaafdil@gmail.com
}

\begin{abstract}
Mindi's leaves (Melia azedarach Linn.) is an Indonesian medicinal plant that used as traditional medicine. Mindi leaves contains some secondary metabolites which have potency to decreased total cholesterol and LDL level. The study purposed to know antihyperlipidemic effect of ethanol extract of mindi's leaves (Melia azedarach Linn.) seen from total cholesterol, and LDL in male albino rats. Male wistar albino rats were divided into 5 groups, negative control group (sodium CMC $0.5 \%$ ), positive control group (simvastatin $0.193 \mathrm{mg} / 200 \mathrm{gBW}$ ), group I (ethanol extract mindi's leaves with dosage $300 \mathrm{mg} / 200 \mathrm{gBW}$ ), group II (ethanol extract mindi's leaves with dosage $600 \mathrm{mg} / 200 \mathrm{gBW}$ ), and group III (ethanol extract mindi's leaves with dosage $1200 \mathrm{mg} / 200 \mathrm{gBW}$ ). The rats were given high-fat supplement and propylthiouracil for 15 days to increase cholesterol, and the extract was given for the next 15 days. Average cholesterol level, LDL, and body weight after induction was $90.28 \mathrm{mg} / \mathrm{dL}, 31.09 \mathrm{mg} / \mathrm{dL}$, and $222.32 \mathrm{~g}$. The result showed ethanol extract mindi's leaves could decreased total cholesterol level and LDL level with \% decreased in total cholesterol (\%PDTC) and \% decreased in LDL (\%PDLDL) of group I is $37.78 \%$ and $35.57 \%$, group II is $45.99 \%$ and $40.39 \%$, and for group III is $56.29 \%$ and $52.42 \%$. The result showed that ethanol extract of mindi's leaves has antihyperlipidemic activity and significantly different from negative control ( $p>0.05$ ). Based on the percentage relation of decreased total cholesterol and LDL levels to dose, then the effective dose 50 (ED50) value of ethanol extract mindis leave is $869 \mathrm{mg} / 200 \mathrm{gBW}$ for total cholesterol and for LDL reduction level is $1086.84 \mathrm{mg} / 200 \mathrm{gBW}$.
\end{abstract}

\section{Keywords}

Melia azedarach Linn, antihyperlipidemia, total cholesterol, low density lipoprotein (LDL)

Received: 21 November 2018, Accepted: 12 January 2019

https://doi.org/10.26554/sti.2019.4.1.222-227

\section{INTRODUCTION}

Hyperlipidemia is the increase in one or more of the total cholesterol, LDL, and triglycerides, or decrease in HDL (Wells et al., 2009). Generally, a person is said to have hyperlipidemia one of the characteristics is if the total cholesterol in the blood exceeds the normal limit (> $200 \mathrm{mg} / \mathrm{dL}$ ). The data results of Riskesdas (2013) shows the prevalence of hyperlipidemia in Indonesia based on the levels of total cholesterol over $240 \mathrm{mg} / \mathrm{dL}$ is of $35.9 \%$. Treatment of hyperlipidemia can be overcome with the use of synthetic drugs (Priyanto, 2009).

The use of synthetic drugs in the long term can cause side effects like myopathy, redness, and itching on the face (Brunton et al., 2008). Many researches on herb plants are done. One of the plants suspected of potentially as antihyperlipidemia is the mindi's leaves (Melia azedarach Linn.).

Mindi leaves (Melia azedarach Linn.) is a plant in the Meliaceae family. The use of mindi leaves traditionally used for malaria, diabetes, coughs, skin diseases, etc (Azam, 2013). The pharmacology activities are related to the content of secondary metabolites in the leaves of mindi.

Mindi leaves are known to contain secondary metabolites including alkaloids, tannins, saponins, phenolics, steroids, terpenoids, and flavonoids (Fitriyani et al., 2016). Flavonoid compounds that act as antioxidants play a role in delaying lipid oxidation processes so as to prevent increases in LDL (Low Density Lipid) and cholesterol total (Davies, 2003). According to Agustina (2009), alkaloid compounds can inhibit lipase enzyme activity that can inhibit the breakdown of fat so that the reduced amount of fat absorbed.

Based on that background, the mindi leaves is thought to have a compounds that can lower blood cholesterol and LDL levels. The aim of this research is to know the potency of mindi leaves ethanol extract in decreasing total blood cholesterol level and LDL level of male white wistar rats induced high fat supplements and propiltiouracil. 


\section{EXPERIMENTAL SECTION}

\subsection{Chemicals}

The ingredients used of simplicia mindi leaves, ethanol $70 \%$, filter paper, dilute $\mathrm{HCl}$, akuades $\mathrm{Mg}$, powder, the reactant reactant Mayer, Wagner, reactant Dragendorff, Alumuniumm chloride, ethyl acetate, anhidirida acetate acid, concentrated sulfuric acid, $\mathrm{FeCl}_{3}$, silica gel plate GF254, fat goats, pig oil, butter, yellow duck egg, feed standard, propiltiourasil, Na CMC, simvastatin, reagent cholesterol (CHOD-PAP), and LDL reagent (polyvinyl sulfate).

\subsection{Plant materials}

Samples of mindi leaves were taken in Plaju of South Sumatera, Indonesia. The sample of mindi leaves was made herbarium and determined by UPT Balai Konservasi Plant of Purwodadi Botanical Garden - LIPI. Sampel was thoroughly washed with tap water, sorted while wet, dried in the shade, and grinded into powder.

The $1000 \mathrm{~g}$ of leaves of mindi simplicia was macerated in $6 \mathrm{~mL}$ of ethanol $70 \%$ for 2 days, then filtered. The filtrate was re-macerated in $4 \mathrm{~mL}$ of ethanol $70 \%$ until the solvent was clear and then re-filtered. The resultant filtrate was then concentrated with a rotary evaporator at $65^{\circ} \mathrm{C}$ at a rate of 40 $\mathrm{rpm}$. This process is done until the concentrated extract is obtained, then calculated the value of rendemen extract etanol leaves mindi (Melia azedarach Linn.). The thick extract was weighed and yield percentage of extract calculated by using equation 1.

\subsection{Preparation of extract}

$$
\% \text { yield }=\frac{\text { obtainedthickextract }}{\text { simpliciausedinextraction }} x 100 \%
$$

\subsection{Extract Characterization}

\subsubsection{Phytochemical Test Using Reagents}

The alkaloid identification was performed by $0.1 \mathrm{~g}$ extracts plus $5 \mathrm{~mL}$ of chloroform and $5 \mathrm{~mL}$ of $0.05 \mathrm{~N}$ ammonia. Filtrate was added $5 \mathrm{~mL} 2 \mathrm{~N} \mathrm{H}_{2} \mathrm{SO}_{4}$ and shaken regularly to form 2 layers. The upper layer is taken then divided into 3 parts, each added 2 drops of Mayer, Wagner, and Dragendorff reagents. If the precipitate is formed then the sample contains alkaloids (Al-Daihan and Bhat, 2012).

Flavonoid test was performed by of $0.5 \mathrm{~g}$ of extracts were again extracted using $5 \mathrm{~mL}$ of hot ethanol for 5 minutes in the test tube. The extraction results are filtered and add a few drops of concentrated $\mathrm{HCl}$ to the filtrate. Enter about $0.2 \mathrm{mg}$ of magnesium metal. Positive tests of flavonoids are characterized by the appearance of red, yellow, or orange. Another way can be done by adding 2 drops of $10 \% \mathrm{NaOH}$ to ethanol extracted filtrate (Al-Daihan and Bhat, 2012).

The saponin test used $0.1 \mathrm{~g}$ viscous extract plus $10 \mathrm{~mL}$ of hot distilled water, then shaken for 10 minutes in a closed state. Extracts containing saponins will form a stable froth for 10 minutes (IndonesianMinistryofHealth, 1977).
Tanin test used a total of $10 \mathrm{~mL}$ of extract was heated for $10 \mathrm{~min}$, then filtered and the filtrate was added with $\mathrm{FeCl}_{3} 1 \%$. A positive extract containing tannin will form a dark blue or dark green (Al-Daihan and Bhat, 2012).

The steroid and triterpenoid identification was performed by $0.1 \mathrm{~g}$ extracts plus $5 \mathrm{~mL}$ of chloroform and $5 \mathrm{~mL}$ of 0.05 $\mathrm{N}$ ammonia. Filtrate was added $5 \mathrm{~mL} 2 \mathrm{~N} \mathrm{H}_{2} \mathrm{SO}_{4}$ and shaken regularly to form 2 layers. The bottom layer added 2 drops of anhydrous acetic acid and 1 drop of concentrated $\mathrm{H}_{2} \mathrm{SO}_{4}$ was added. If a bluish or greenish color is present it is positive for steroids, while brownish red color indicates positive for terpenoids (Al-Daihan and Bhat, 2012).

Phenolic test was performed by extract of $1 \mathrm{~mL}$ of hot water, then added a few drops of $\mathrm{FeCl}_{3} 1 \%$ reagent. Positive test is shown by the formation of green, blue or purple.

\subsubsection{Flavonoids test with Thin Layer Chromatography}

The flavonoid identification was done by of an ethanol extract solution of $70 \%$ of the mindi leaves on the TLC plate measuring $5 \times 1 \mathrm{~cm}$. The TLC plate was then eluted with eluent in a saturated chamber, a mixture of ethanol and ethyl acetate $(8: 2)$. TLC was eluted by observation of spots on UV lights 254 and $366 \mathrm{~nm}$, after which sprayed with Aluminum chloride and caused yellow spots after spraying.

\subsection{Test Animal Preparation}

The test animal used was white male rats Wistar aged $2-3$ months with $150-200 \mathrm{~g}$ weight of 24 tails. The treatment group was divided into 6 groups as in Table 1 .

\subsection{Induction of Fat Supplements and PTU}

Test animals in all groups were induced with a high-fat supplement and $0.01 \%$ propylthiouracil solution for 14 days orally to obtain hyperlipidemic conditions in mice $(>54 \mathrm{mg} / \mathrm{dL}$ for total cholesterol and $>27.2$ for LDL). Blood sampling was performed on day 15 to determine total cholesterol and rat LDL levels.

\subsection{Antihiperlipidemia Activity Test}

Rats with a total cholesterol of more than $54 \mathrm{mg} / \mathrm{dL}$ and LDL over $27.2 \mathrm{mg} / \mathrm{dL}$ were used to continue in antihiperlipidemia testing. The division of animal group test as in Table 1 of each group was given treatment in each dose of each test preparation once every 1 day for 14 days orally. The weight of the test animal was weighed during the treatment.

\subsection{Measurement of Total Cholesterol and LDL}

$2 \mathrm{~mL}$ Rat blood was taken with a hematocrit pipette in the retroorbital plexus section. Blood was silenced for 15 minutes and centrifuged for 10 minutes at $5000 \mathrm{rpm}$. Blood serum is piped with a $10 \mu \mathrm{L}$ micro pipette and inserted in a test tube. Serum is then fed into the bio system analyzer. CHOD-PAP cholesterol reagent solution was added to $1000 \mu \mathrm{L}$ samples, blanks and standards for total cholesterol measurements while for LDL level measurements added polyvinyl sulphate reagents 
Table 1. The design of animal test groups

\begin{tabular}{ll}
\hline Groups & Treatment \\
\hline Negative Control & High fat supplement + Propiltiouracil 0.01\% + Sodium CMC 0.5\% \\
Positive Control & High fat supplement + Propiltiouracil 0.01\% + Simvastatin dose $0.193 \mathrm{mg} / 200 \mathrm{gBW}$ \\
Group I & High fat supplement + Propiltiouracil $0.01 \%+$ suspension extract of mindi leaves dose \\
& $300 \mathrm{mg} / 200 \mathrm{gBW}$ \\
Group II & High fat supplement + Propiltiouracil $0.01 \%$ + suspension extract of mindi leaves dose \\
& $600 \mathrm{mg} / 200 \mathrm{gBW}$ \\
Group III & High fat supplement + Propiltiouracil $0.01 \%+$ suspension extract of mindi leaves dose \\
& $600 \mathrm{mg} / 200 \mathrm{gBW}$ \\
\hline
\end{tabular}

$\mathrm{ED}_{50}$ was calculated based on the correlation between percentage effect of decreasing total cholesterol and LDL on the dose of extract analyzed using linear regression.

\subsection{Data Analysis}

The data obtained were statistically analyzed by Shapiro-Wilk normality test to find out whether the data obtained had a normal distribution ( $p>0.05)$. Normally distributed data is continued with paired t-test and one way ANOVA using SPSS 16.0 For Windows program with provisions if $\mathrm{p}<0.05$ then there is a significant difference, but if the data is not normally distributed then proceed with Kruskal-Wallis non parametric test.

\section{RESULTS AND DISCUSSION}

\subsection{Preparation Of Extract}

Mindi leaf extract was obtained through a process of maceration using $70 \%$ ethanol solvent. The choice of the ethanol as solvent because ethanol (70\%) is very effective in generating the optimal amount of the active ingredient. Maceration was chosen because of the extracted target compounds are compounds of flavonoids not resistant to warming and easily oxidized at high temperature $\left(>90^{\circ} \mathrm{C}\right.$ ) (Francis et al., 2002).

Maseration results concentrated with a rotary evaporator with a rotation speed of $40 \mathrm{rpm}$ at a temperature of $65^{\circ} \mathrm{C}$ to obtain viscous extract. The extraction process is done using powder simplisia mindi leaves as many as 1000 grams and produce a thick extract of 238.96 grams with the percentage yield of $23.896 \%$. The yield of rendement can also indicate the possible amount of chemical compounds contained in the extract.

\subsection{Phytochemical Screening Extracts}

Based on phytochemical screening tests in Table 2, a positive reactions to the testing of flavonoids, alkaloids, tannins, phenolics, saponins, and steroids, but gave a negative reaction to triterpenoids.

\subsection{Identification of Flavonoids using TLC}

The identification of flavonoid compounds on mindi leaves ethanol extract was performed by qualitative test using thin
Table 2. Phytochemical test of extract by using reagent

\begin{tabular}{cc}
\hline Secondary Metabolite & Extract \\
\hline Flavonoid & + \\
Alkaloid & + \\
Tannin & + \\
Phenolic & + \\
Saponin & + \\
Steroid & + \\
Triterpenoid & - \\
\hline Description: $(+)$ positive and (-) negative
\end{tabular}

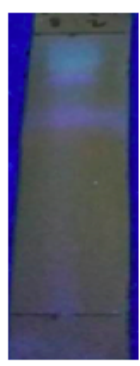

(a)

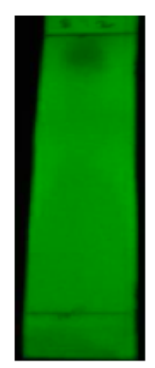

(b)

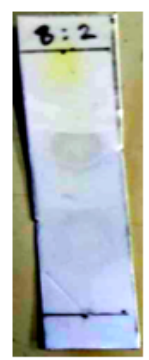

(c)
Figure 1. TLC results of ethanol extract of mindi leaves (a) UV 254 (b) UV 366 (c) $\mathrm{AlCl}_{3}$ stain appearance

layer chromatography (TLC). The stationary phase used is a silica gel plate measuring $5 \mathrm{~cm} \times 1 \mathrm{~cm} \mathrm{GF} 254$ (Merck), while the mobile phase used is ethanol:ethyl acetate (8:2) capable of providing the best separation. Flavonoid compound group examinations were detected under $366 \mathrm{~nm}$ and $254 \mathrm{~nm} \mathrm{UV}$ light. TLC results are reacted with aluminum chloride spray reagent to detect flavonoids. Spray reagents used to identify flavonoid compounds include $\mathrm{AlCl}_{3}$. Based on the results of extract chromatogram with aluminum chloride spray reagent showed yellow color. The flavonoid compounds in the ethanol extract of the mindi leaves will bind to aluminum (Al) to form a yellow stable complex (Grundy, 1991)). 


\subsection{Provision of Dosage and Induction of Test Animal}

Wistar male white rats used had a $2-3$ month age criterion and weighed $\pm 200 \mathrm{~g}$. Male white rats were selected as test animals because they had better hormonal stability compared with female white rats. Female white rats have a period of esterus, pregnancy, and estrogen hormones that can influence the results of observation (Pratiwi, 2010).

The process of acclimatization is done during one week aims to adopt rats on laboratory conditions so that it does not appear the stress in rat. The next test animals were given induction of high-fat supplements are per oral for 15 days to increase the total and LDL cholesterol levels in rat. In addition to induction with high-fat supplements, animal tests are also given propiltiourasil (PTU) per oral. Propiltiourasil worked as a antitiroid that inhibits thyroid cells in rat so that the production of thyroid hormone is inhibited and leads to hypothyroidism (Rahayuningsih and Tita, 2015).

\subsection{Measurement of Weighted Animal Test}

Weight observations were performed to see the differences in body weight between treatment groups and to see if there was any effect of high-fat supplementation on body weight of the test animals. The results showed that the weight of all test animals increased after the administration of high-fat supplements for 14 days and there were significant differences $(\mathrm{p}<0.05)$. That is, the provision of high-fat supplements can increase body weight test animals.

After being treated according to Table 1 all the test animals lost weight and there were significant differences $(\mathrm{p}<0.05)$, which showed that the extract of mindi leaves ethanol was able to decrease the weight of the test animals. Weight loss is caused by the content of the compounds that exist in the extract including flavonoid compounds. Flavonoids can inhibit FAS (Fatty Acid Synthase) by blocking Acetil-CoA and Malonil$\mathrm{CoA}$ so as to inhibit genes that play a role in adipogenesis thereby decreasing the amount of adipocytes (Jeyakumar et al., 2005).

The positive control group experienced considerable weight loss, this is due to the provision of simvastatin in positive control which is the enzyme inhibitor HMG-CoA reductase which can disrupt the cholesterol synthesis in the liver so that it can lower the triglyceride level. Decreased triglyceride levels cause storage in adipose tissue is also decreased (Kasim et al., 1992).

\subsection{Measurement of Total Cholesterol and LDL}

Measurement of total cholesterol and LDL in this study was done 3 times after acclimation, after the induction of high-fat supplements, and after the provision of the test material. Blood is taken in the retroorbital part of the rat's eye because the blood collection is relatively fast and smooth so as to minimize the occurrence of hemolysis. 16 The results of measurement of total cholesterol and test animals can be seen in Table 3 and Table 4.

The normal range for total cholesterol in mice was 10-54 $\mathrm{mg} / \mathrm{dL}$ (Harini, 2009), whereas in LDL was $7-27.2 \mathrm{mg} / \mathrm{dL}$

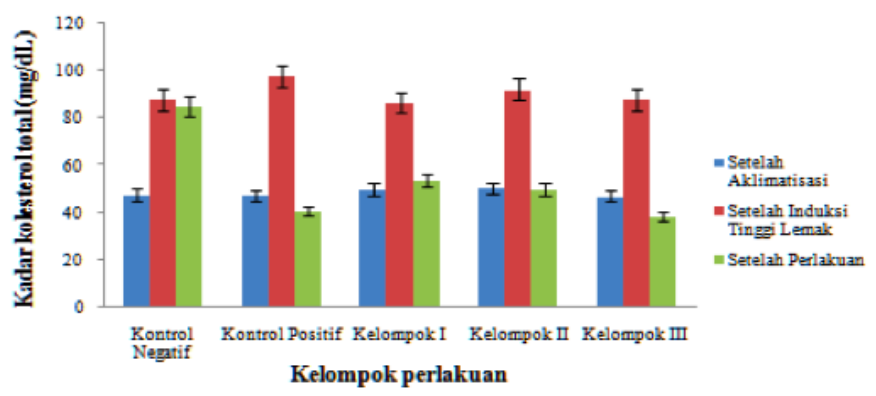

Figure 2. Graph of decrease in total cholesterol level of test animals (mg/dL)

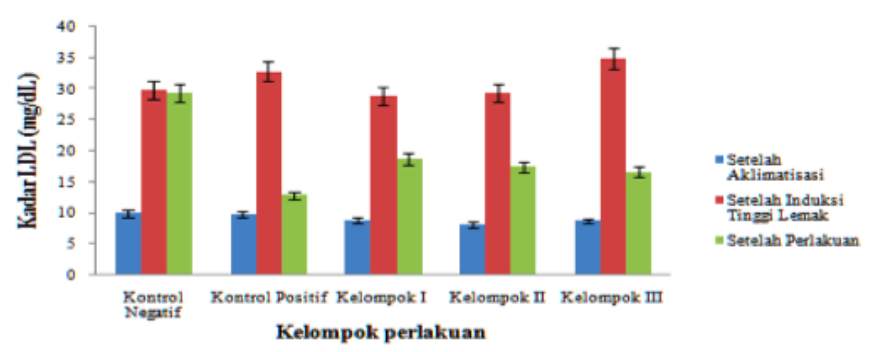

Figure 3. Graph of decrease in LDL level of test animals $(\mathrm{mg} / \mathrm{dL})$

(Herwiyarirasanta, 2010). The results showed that there was an increase in total cholesterol levels and after the induction of high-fat supplements and PTU significantly $(p<0.05)$. This proves that the induction of high-fat supplements for 14 days was able to increase total cholesterol and LDL levels significantly.

This is in line with the statement of Grundy (1991) that the consumption of foods rich in fatty acids and cholesterol can inhibit the formation of LDL receptors, so that cholesterol accumulates in the blood. While the role of PTU is as antithyroid substances that can damage the thyroid gland and cause hypothyroid conditions. Under these conditions, there is a decrease in synthesis and expression of LDL receptors in the tissues. Therefore, LDL circulates much in the blood and causes hyperlipidemia.21 The results of the total cholesterol and LDL test after treatment showed that the test material at three doses and positive controls decreased total cholesterol and LDL levels significantly $(\mathrm{p}<0.05)$ when compared with the negative controls (Figures 2 and 3 ).

The results showed the highest decrease in total and LDL cholesterol occurred in the positive control group. The positive control group experienced a decrease in total cholesterol levels due to the presence of simvastatin which has a structure similar to HMG-CoA reductase, works by inhibiting HMG-CoA reductase competitively in the cholesterol synthesis process in the liver (Suyatna, 2007).

The negative control group experienced only a slight decrease in total cholesterol and LDL levels. This is because the 
Table 3. Results of Measurement Total Cholesterol of Animal Test

\begin{tabular}{ccccc}
\hline \multirow{2}{*}{ The treatment groups } & \multicolumn{3}{c}{ Average levels of Total cholesterol $(\mathrm{mg} / \mathrm{dL}) \pm \mathrm{SD}$} & \multirow{2}{*}{ Average Decline } \\
\cline { 2 - 4 } & After Acclimatization & After induction of high-fat*a & after treatment*b & \\
\hline Negatif Controls & $47.49 \pm 6.29$ & $87.85 \pm 2.08$ & $84.65 \pm 1.44$ & $3.20 \pm 2.3$ \\
Positive Controls & $47.4 \pm 5.86$ & $97.69 \pm 3.87$ & $40.47 \pm 4.93$ & $57.23 \pm 8.08$ \\
Group I & $49.84 \pm 3.34$ & $86.37 \pm 6.57$ & $53.74 \pm 8.78$ & $32.63 \pm 2.22$ \\
Group II & $50.25 \pm 5.54$ & $91.91 \pm 3.46$ & $49.64 \pm 8.63$ & $42.27 \pm 11.33$ \\
Group III & $46.79 \pm 2.05$ & $87.57 \pm 5.82$ & $38.27 \pm 6.80$ & $49.30 \pm 12.21$
\end{tabular}

Description: *a: $\mathrm{p}<0.05$ data differ significantly to the value after acclimation *b: $\mathrm{p}<0.05$ data differ significantly to the value after induction

Table 4. Results of Measurement LDL of Animal Test

\begin{tabular}{ccccc}
\hline \multirow{2}{*}{ The treatment groups } & \multicolumn{3}{c}{ Average levels of Total cholesterol $(\mathrm{mg} / \mathrm{dL}) \pm \mathrm{SD}$} \\
\cline { 2 - 4 } & After Acclimatization & After induction of high-fat*a & after treatment*b & \\
\hline Negatif Controls & $9.84 \pm 1.56$ & $29.83 \pm 2.02$ & $29.36 \pm 1.94$ & $0.46 \pm 0.31$ \\
Positive Controls & $9.80 \pm 2.20$ & $32.77 \pm 3.65$ & $12.74 \pm 3.16$ & $20.03 \pm 5.08$ \\
Group I & $8.79 \pm 2.17$ & $28.82 \pm 1.15$ & $18.62 \pm 2.12$ & $10.81 \pm 1.14$ \\
Group II & $8.02 \pm 0.22$ & $29.23 \pm 1.01$ & $17.43 \pm 1.93$ & $11.81 \pm 2.89$ \\
Group III & $8.63 \pm 0.81$ & $34.83 \pm 4.13$ & $16.57 \pm 1.58$ & $18.26 \pm 2.82$
\end{tabular}

Description: *a: $\mathrm{p}<0.05$ data differ significantly to the value after acclimation *b: $\mathrm{p}<0.05$ data differ significantly to the value after induction

test animals on negative controls are only given a solution of sodium CMC that serves as a suspending agent and not given anything that could potentially reduce total cholesterol levels so that the cholesterol levels of test animals only slightly decreased. The occurrence of decreased total cholesterol levels in the negative control one of them can be caused by the diet of cholesterol, fatty acids, and calories. Naturally, the body can degrade excess cholesterol to bile acids (Murray et al., 2006).

The results showed that the extract of mindi ethanol leaves can lower total cholesterol and LDL of test animals. The dose of mindi leaf extract is best in lowering cholesterol and LDL levels in group III treatment $(1200 \mathrm{mg} / 200 \mathrm{gBB})$. This is due to the presence of metabolite compounds contained in the extract of ethanol leaves mindi. The result of statistical test with t-pair showed significant difference of total cholesterol and LDL of test animal before and after treatment $(\mathrm{p}<0,05)$.

The results of phytochemical screening showed that the extract of mindi ethanol contains flavonoid compounds, alkaloids, tannins, phenolics, saponins and steroids. The possibility of such a decrease effect is due to the compounds of the group. Flavonoids work by reducing cholesterol synthesis by inhibiting the activity of 3-hydroxy-3-methyl-glutaril-CoA enzyme causing inhibition of cholesterol synthesis (Arief et al. 2012). Flavonoids can affect the metabolic process of LDL cholesterol by increasing the ability of LDL to bind to its receptors (Wilcox et al., 2001). The mechanism of tannin compounds in the extract of ethanol leaves mindi to decrease LDL levels is by inhibiting the work of the enzyme HMG-CoA reductase, the enzyme that play a role in the formation of cholesterol. Research Francis et al (2002) states that saponins can lower serum sodiumol levels with the possibility of binding saponins with cholesterol.

Data analysis was performed using SPSS $₫$ application, it is known that normality test of total cholesterol and LDL data is normally distributed with significance value $>0.05$. Test of total cholesterol and LDL using one way ANOVA obtained significance value $\mathrm{p}<0.05$ which states that data have relationship and significant. One way ANOVA was performed to observe differences in data in one test group, so that based on these data, there were significant differences in cholesterol and LDL levels between groups. Result of post hoc test analysis, it is known that there is no significant difference of data of decrease of cholesterol and LDL level between positive control group with group I, II, and III ( $p>0.05)$. The positive control group and groups I, II, and III showed a significant difference with the negative control group $(\mathrm{p}<0.05)$.

\subsection{Effective Dose $\left(\mathrm{ED}_{50}\right)$}

According to the Department of Pharmacology and Therapeutic FKUI (2011), a $50 \%$ effective dose $\left(\mathrm{ED}_{50}\right)$ is a dose that has a therapeutic effect on $50 \%$ of individuals (median dose of therapy). $\mathrm{ED}_{50}$ reduction in total cholesterol levels was calculated by linear regression between doses with percent decrease in total cholesterol (\% PDTC) (Fig. 4). Linear regression equation obtained is $\mathrm{y}=0.020 \mathrm{x}+32.62$ with value $\mathrm{R}^{2}=0.984 .\left(\mathrm{ED}_{50}\right)$ results show that $\left(\mathrm{ED}_{50}\right)$ from mindi leaves ethanol extract is 


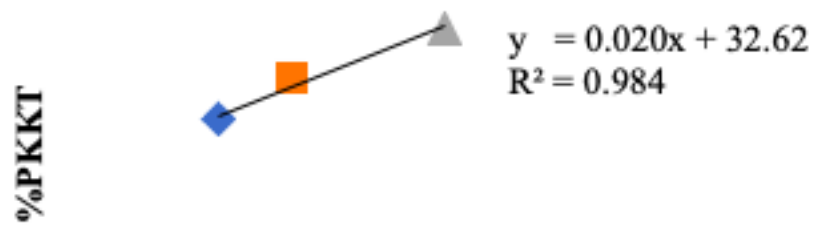

Figure 4. Graph of linear regression between doses $(\mathrm{mg} / 200$ gBB) and \%PDTC extract etanol leaves mindi

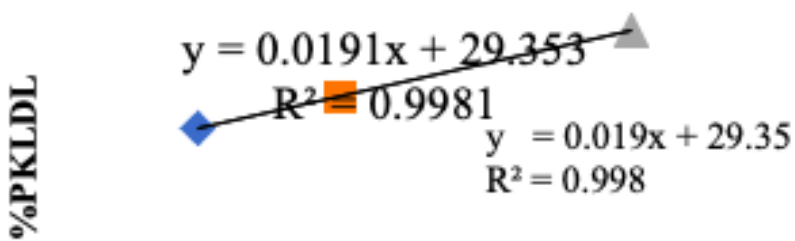

Figure 5. Graph of linear regression between doses $(\mathrm{mg} / 200$ $\mathrm{gBW}$ ) and \%PDLDL extract etanol leaves mindi

$869 \mathrm{mg} / 200 \mathrm{gBW}$.

$\mathrm{ED}_{50}$ reduction in total cholesterol levels was calculated by linear regression between doses with percent decrease in LDL (\%PDLDL) (Figure 5). Linear regression equation obtained is $\mathrm{y}=0.019 \mathrm{x}+29.35$ with value $\mathrm{R}^{2}=0.998$. The result of $\mathrm{ED}_{50}$ calculation shows that $\mathrm{ED}_{50}$ from mindi leaves ethanol extract is $1086.84 \mathrm{mg} / 200 \mathrm{gBW}$.

\section{CONCLUSIONS}

Based on the result and discussion it can be concluded that the dosage of ethanol extract of mindi leaf has an effect on decreasing total cholesterol level of white male rat of Wistar strain with\% PDTC at dose $300 \mathrm{mg} / 200 \mathrm{gBW} 37.78 \%$, at dose $600 \mathrm{mg} / 200 \mathrm{gBW}$ equal to $45.99 \%$, and at a dose of 1200 $\mathrm{mg} / 200 \mathrm{gBW}$ of $56.29 \%$. The extract of ethanol leaves mindi influenced in decreasing LDL level of Wistar male white rat with\% PDLDL dose $300 \mathrm{mg} / 200 \mathrm{gBW} 35.37 \%$, dose 600 $\mathrm{mg} / 200 \mathrm{gBW}$ equal to $40.39 \%$, and dose $1200 \mathrm{mg} / 200 \mathrm{gBW}$ equal to $52.42 \%$. The ED50 value of ethanol extract of mindi leaves to lower total cholesterol was $869 \mathrm{mg} / 200 \mathrm{gBW}$, whereas to decrease LDL was $1086.84 \mathrm{mg} / 200 \mathrm{gBW}$.

\section{ACKNOWLEDGEMENT}

Authors would like to express their gratitude toward Sriwijaya University PNBP Kompetitif Research Grant that made this research possible.

\section{REFERENCES}

Agustina, R. (2009). Efek pemberian ekstrak etanol 70(Psidium guajava L.) bagian dalam terhadap kadar kolesterol dalam serum darah tikus putih jantan wistar (Rattus norvegicus). Master's thesis, Jurusan Kedokteran, Fakultas Kedokteran, Universitas Muhammadiyah, Surakarta, Indonesia.

Al-Daihan, S. and R. Bhat (2012). Antibacterial activities of extracts of leaf, fruit, seed, and bark of Phoenix dactylifera. Africa Journal Biotechnology, 11(42); 10021-10025

Azam, M. M. (2013). Pharmacological potentials of Melia azedarach L. A review. American Journal of BioScience, 1; 44 $-49$

Brunton, L., K. Parker, D. Blumenthal, and L. Buxton (2008). Goodman E Gilman's Manual Of Pharmacology And Therapeutics. McGraw - Hill, New York, USA

Davies, M. e. a. (2003). Black tea consumption reduces total and LDL cholesterol in mildly hypercholesterolemic adults. journal nutrition, 133(10); 3298 - 3302

Fitriyani, D. Kusrini, and E. Fachriyah (2016). Isolasi, identifikasi, dan uji sitotoksik senyawa alkaloid dari daun Mindi (Melia azedarach Linn). JKPK, 1(2); $33-40$

Francis, G., K. Zohar, P. Harider, and B. Klaud (2002). The ciological action of saponins in animal systems. British Journal of Nutrition, 88; $587-605$

Grundy, S. (1991). Multifactorial ethiology of hypercholesterolemia: Implication for prevention of coronary heart desease,. Artherioschlerosi and Thrombosis, 11; 1619 - 1635

Harini, M. (2009). Blood cholesterol level of hypercholesterolemia rat (Rattus norvegicus) after VCO treatment. Journal Bioscience, 1(2); 53 - 58

Herwiyarirasanta (2010). Effect of black soybean extract supplementation in low density lipoprotein level of rats (Rattus norvegicus) with high fat diet. Universitas Airlangga, Surabaya

IndonesianMinistryofHealth (1977). Materia Medika Indonesia. Indonesian FDA, Jakarta

Jeyakumar, S., A. Vajreswari, B. Sesikeran, and Giridharan (2005). Vitamin A supplementation induced adipose tissue loss through apoptosis in lean but not in obeses rats of WNIN/Ob strain. Journal of Moleculer Endrocrinology, 35; $391-398$

Kasim, S., C. Renee, W. Sheila, T. Lalitha, D. Dewundra, and C. J (1992). Mechanism of tryglyceride-lowering effect of an HMG-CoA reductase inhibitor in a hypertriglyceridemic animal model the Zucker obese rat. journal Lipid Research, 33; $1-7$

Murray, K., D. Granner, and V. Rodwell (2006). Biokimia harper (diterjemahkan), ed. ke-27. Buku Kedokteran EGC, Jakarta

Pratiwi, N. (2010). Hubungan high density lipoprotein dengan penurunan fungsi kognitif pada wanita post menopause. Master's thesis, Jurusan Ilmu Kesehatan Masyarakat, Fakultas Kesehatan Masyarakat, Universitas Muhamaadiyah, Surakarta, Indonesia 
Priyanto (2009). Farmakoterapi and Terminologi Medis. Leskonfi, Depok, Indonesia

Rahayuningsih, N. and N. Tita (2015). Efek antihiperlipidemia ekstrak etanol buah strawberry (Fragraria $\mathrm{x}$ ananassa Duchesne) pada tikus putih dari daerah Bandung. JKBTH, 13(1); $1-8$

Suyatna, F. (2007). Hipolipidemik. Dalam S.G Gunawan, R. Setiabudy, Nafrialdi, dan Elysabeth (ed. ke-5). Farmakologi dan Terapi, Departemen Farmakologi dan Terapeutik Fakultas Kedok- teran. Universitas Indonesia, Jakarta, Indonesia

Wells, B., J. Dipiro, T. Schwinghammer, and C. Dipiro (2009). Pharmacotherapy handbook (7th ed.), volume 98. The McGrawHill Medical, New York

Wilcox, L., N. Borradaile, L. de Dreu, and H. M.W (2001). Secretion of hepatocyte apoB is inhibited by the flavonoids, naringenin and hesperetin, via reduced activity and expression of ACAT2 and MTP. Journal Lipid Research, 42; 725 734 